\title{
Concrete Debris as Alternative Fine Aggregate for Architectural Finishing Mortar
}

\author{
Tomas Ucol-Ganiron Jr
}

Department of Architecture, Design and Planning, Qassim University, Buraidah City, 51452, KSA

\begin{abstract}
This experimental study aimed to design a mixture of crushed concrete debris as alternative fine aggregate for architectural finishing mortar. A conventional mortar was compared to concrete debris of the same proportions. Observations fro $m$ the tests performed were conducted in the laboratory where prec ise data were gathered and completely attained. So me of the interesting insights of the study are: (a) the proportion of the crushed concrete debris affects cement and water in a manner that it absorbs most of the water in the mixture; (b) the concrete debris mixture obtained a high slump and low compressive strength at its seventh day of curing; (c) the consistency of the mixture is affected by the amount of water in the mixture and (d) the concrete debris mix, with $1: 23 / 4$ cement to crushed concrete debris ratio has an acceptable mobility as the standard mortar mix of the same cement to sand ratio with considerable slumps and penetration.
\end{abstract}

Keywords Concrete Debris, Mortar Mixture, Fine Aggregate

\section{Introduction}

As time goes by, the development in the construction industry all over the world is progressing. Many structures are being built, both residential and non residential, as well as roads and bridges. Just like many countries, the demand for new structures in the Philippines is highly increasing. High-tech and modernized designs are built and old buildings are demolished or renovated[1]. The resulting non-hazardous and uncontaminated materials are called debris. These include asphalt, bricks, concrete(ABC) and other masonry materials, soil, rock, wall coverings, drywalls, plumbing fixtures, insulation, roofing, shingles, plates glass, metal wood waste, carpet and electrical wires[1],[2]. These materials can be separated and salvaged prior to disposal.

One of the things builders, developers and contractors must consider during construction, renovation or demolition is where to put all the debris. As what most people do in the preservation of the environment and for economic purposes, studies, researches and experiments are being done to find solution considering where else to put debris and what can be done to lessen its disposal landfill to disposal and since, there is an increasing environmental problem regarding the waste disposal to landfills, it is necessary to think of possible ways on how to avoid these problems and at the same time secure safety and convenience, and

* Corresponding author:

tomas@qec.edu.sa (Tomas Ucol-Ganiron Jr)

Published online at http://journal.sapub.org/arch

Copyright (C) 2012 Scientific \& Academic Publishing. All Rights Reserved that is, to recycle.

When structures made of concrete are to be demolished, concrete recycling is an increasingly common method of disposing of the rubble. Concrete debris was once routinely shipped to landfills for disposal, but recycling has a number of benefits that has made it more attractive option in this age of greater environmental awareness, more environmental laws, and the desire to keep construction costs down. Major motivators include the realization that using recycled materials can achieve cost savings, qualify for tax savings, improve product performance and meet recycling goals[3]. It is beneficial in two ways: it reduces the inputs (energy and raw materials) to a production system and reduces the amount of water produced for disposal.

In this study, the researcher is aiming to design a concrete debris mixture as mortar mix that will meet the ASTM requirements, in order to help contribute to the industry in saving the environment, to encourage the government to find solutions regarding the disposal to landfills of waste materials and save the environment, to provide new knowledge to the contractors and developers on how to improve the construction industry methods and services by using recycled concrete debris, and to sustain good product performance and meet recycling goals.

\section{Project Development}

As shown in figure 1, a chart is shown to illustrate the development of the project.

In the development of this study, the researcher collected pieces of uncontaminated concrete debris from demolished 
residential structures.

These pieces of debris were crushed manually using hammer and graded according to the Standard Specification for Sand and Masonry Mortar specified in ASTM C144, for manufactured sand, which is a 100 percent passing for No. 4 sieve and 10 percent passing the No. 200 sieve. The graded crushed concrete debris were mixed with water and cement with 1: 3 ratio of cement to crushed concrete debris [3],[4].

After three to five minutes of mixing a slump test was performed on the mixture with the addition of water until a desired flow was obtained, and five specimens were test for penetration. Another five specimens for $7^{\text {th }}, 14^{\text {th }}, 21^{\text {st }}$, and $28^{\text {th }}$ day of curing were tes ted for compression test. A conventional mortar was also tested in the same manner.

The results were evaluated whether the mixture failed or if it passed the standard for mortar. If it fails to meet the ASTM requirements: redesign the mixture, if it meets the ASTM requirements, then adopt the design mixture[5].

In order to come up with the output of the research, which is a design mixture of crushed concrete debris, various tests and experiments were made such as sieve analys is, ball penetration test, slump test and compression test[6].

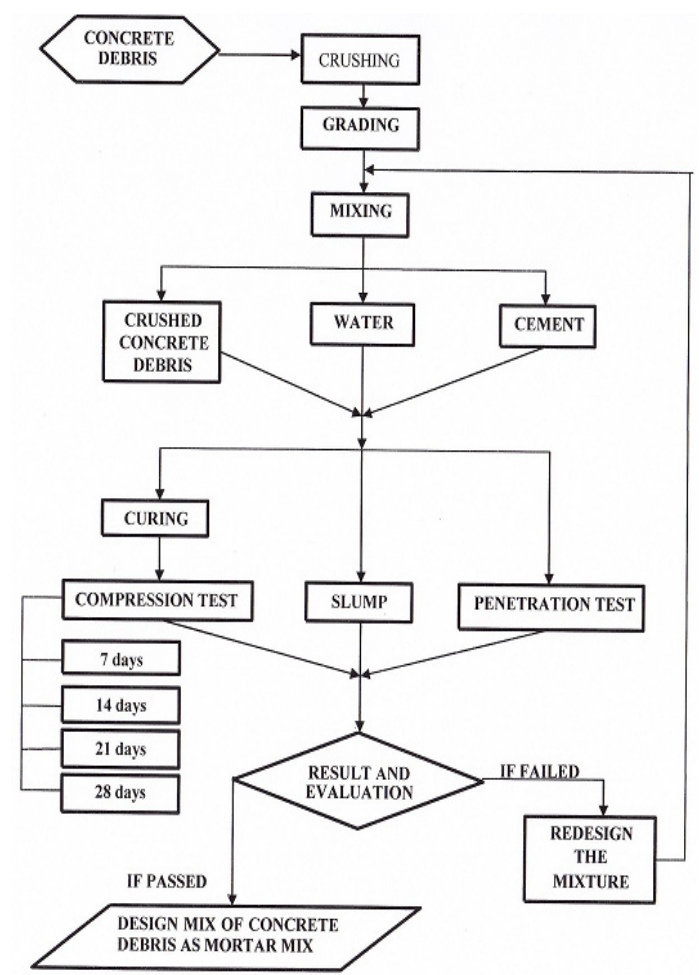

Figure 1. Project Development

\section{Testing of Mortar Mixture}

This study aimed to determine the compressive strength using the Universal testing machine (UTM), and the workability of the concrete debris mixture in terms of consistency, mobility and compactness using 2-in cube specimens.

In addition, this study intends to identify the mix proportion of the concrete debris mixture, and the factors that affect its consistency and instability[7].

\subsection{Mix Proportion of the $S$ pecimen}

The mixture design for compression and penetration tests are $24 \%$ cement, $11 \%$ water, and $65 \%$ crushed concrete debris make up the mortar mix. The amount of water is increased from $11 \%$ to $60 \%$ due to the need to find the slum of the mixture for slump test.

Based fro $m$ the values obtained on water and cement ratio to concrete debris, the amount of water for every $250 \mathrm{~g}$ of concrete debris is $36.36 \mathrm{~g}$ and cement is $90.90 \mathrm{~g}$. This is applicable for 20 in cube specimens used for compression and penetration tests.

\subsection{Sieve Analysis of Crushed Concrete Debris}

Table 1 shows the result of the graded crushed concrete debris using sieve analysis according to the ASTM C144, standard specification for sand and masonry mortar with $100 \%$ passing the No. 4 sieve and 10\% passing the No. 200 sieve[8].

Table 1. Sieve Analysis of Crushed Coarse Debris

\begin{tabular}{|c|c|c|c|c|c|}
\hline $\begin{array}{c}\text { Sieve Size } \\
(\mathrm{mm})\end{array}$ & $\begin{array}{c}\text { Mass } \\
\text { Retained (g) }\end{array}$ & \multicolumn{3}{|c|}{ Cumulative } & Specification, \\
\% passing \\
\cline { 3 - 6 } & & $\begin{array}{c}\text { Nass Passing } \\
(\mathrm{g})\end{array}$ & \% Passing & \% Retained & \\
\hline 4.750 & 9.76 & 1365.24 & 99.29 & 0.71 & 100 \\
\hline 2.360 & 59.63 & 1305.61 & 95.63 & 4.37 & $95 \cdot 100$ \\
\hline 1.180 & 94.67 & 1210.94 & 92.74 & 7.26 & $70 \cdot 100$ \\
\hline 0.600 & 386.14 & 824.80 & 68.11 & 6.89 & $40 \cdot 75$ \\
\hline 0.300 & 528.36 & 296.44 & 35.94 & 4.06 & $20 \cdot 40$ \\
\hline 0.150 & 234.82 & 61.62 & 20.79 & 4.21 & $10 \cdot 25$ \\
\hline 0.075 & & & 1.00 & 9.00 & 0.10 \\
\hline Pan & 61.62 & & & & \\
\hline Total & 1375.00 & & & & \\
\hline
\end{tabular}

\subsection{Penetration Test of Standard and Concrete Debris Mix}

Table shows the different values of penetration of each five specimens of the two mixtures. The average difference of the penetration of the standard mix is $8.61 \%$ higher than the average penetration of the concrete debris mixture. However, the penetration must be read from the nearest $1 / 4$ in $(6.4 \mathrm{~mm})$. Hence, the penetration of the concrete debris mixtu re passed the allowed penetration for mortar[9].

Table 2. Penetration Test of Standard and Concrete Debris Mix

\begin{tabular}{|c|c|c|c|}
\hline Standard Mix & $\begin{array}{c}\text { Penetration } \\
(\mathbf{m m})\end{array}$ & $\begin{array}{c}\text { Concrete } \\
\text { Debris Mix }\end{array}$ & $\begin{array}{c}\text { Penetration } \\
(\mathbf{m m})\end{array}$ \\
\hline 1 & 3.8 & 1 & 4.0 \\
\hline 2 & 5.0 & 2 & 5.5 \\
\hline 3 & 4.5 & 3 & 5.9 \\
\hline 4 & 5.0 & 4 & 5.0 \\
\hline 5 & 4.0 & 5 & 4.0 \\
\hline Average & 4.46 & Average & 4.88 \\
\hline
\end{tabular}




\subsection{Slump of Standard and Concrete Mix}

The slump of standard mix is 7.2 inches while concrete debris mix has a slump of 7.3 inches. In this test, the difference of slump values is only 0.1 inch. However, the slumps of the two mixtures were obtained with the addition of water from $11 \%$ to $60 \%$. The required slump for mortar is fro $\mathrm{m}$ 5-8 inches. Therefore, the slu mp of the concrete debris mixture passed the required slump for mortar.

\subsection{Compressive Strength of Standard Mix and Concrete Debris Mix}

Figure 2 shows the variation of the average stresses of the standard mix and the concrete debris mixture, which were both cured for 7, 14, 21 and 28 days. The highest average compressive strength for each mixture was obtained on the $28^{\text {th }}$ day of curing. It also shows that the standard mortar mixture results to an average compressive stress of $17.61 \%$ higher than the concrete debris mixture on the $28^{\text {th }}$ day. However, the average compressive strength of the concrete debris mix is above the allowable compressive strength of $\operatorname{mortar}[10]$.

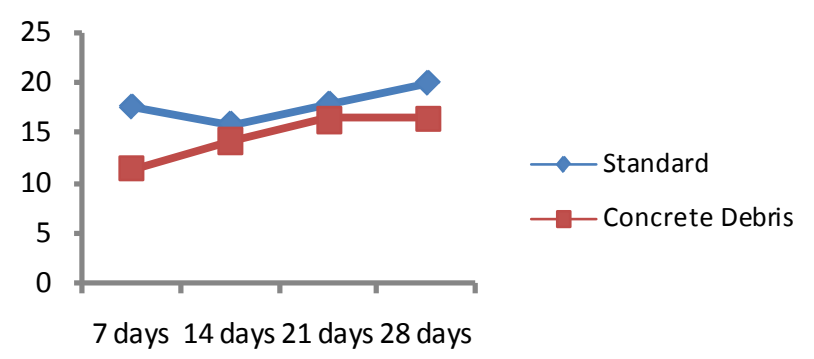

Figure 2. Average Compressive Strength of Standard Mix and Concrete Debris Mix

\subsection{Compressive Strength at $28^{\text {th }}$ days of Cement Sand Gravel Mix \& Cement Concrete Debris Water Mix}

Table 3 shows that the compressive strength at $28^{\text {th }}$ day of cement-sand-gravel mix with 1:3:6 ratio is $13.8 \mathrm{MPA}$ and the cement-concrete debris-water mix with ratio of $1: 23 / 4$ : $61 / 4$ has $16.384 \mathrm{MPA}$ compressive strength at $28^{\text {th }}$ day[11].

Table 3. Penetration Test of Standard and Concrete Debris Mix

\begin{tabular}{|c|c|c|c|c|c|c|c|c|}
\hline Cement & Sand & Gravel & $\begin{array}{c}\text { Compressive } \\
\text { Strength(MPA) }\end{array}$ & Cement & Sand & Water & $\begin{array}{c}\text { Compressive } \\
\text { Strength } \\
\text { (MPA) }\end{array}$ \\
\hline Ratio & 1 & 1 & 3 & 6 & $13: 8$ & $2 \% 14$ & $6 \% 14$ & 16.384 \\
\hline
\end{tabular}

\subsection{Cost Analysis}

Table 4 shows the estimated cost between the standard mortar mix and the concrete debris mix. The total amount shown for the use of crushed concrete debris is just an estimate of the demolition activity, (the cost of the crushed concrete debris is not yet included), and the values show that the standard mortar mix(including labor and material costs)is cheaper than the crushed concrete debris $\operatorname{mix}[12]$.
Table 4. Cost Analysis

\begin{tabular}{|c|c|c|c|c|c|}
\hline Unit & $\begin{array}{c}\text { Standard } \\
\text { Mix }\end{array}$ & Price Estimated & Unit & $\begin{array}{c}\text { Concrete Debris } \\
\text { Mix }\end{array}$ & Price Estimated \\
\hline $40 \mathrm{~kg}$ bag & Cement & $\$ 4.20$ & $40 \mathrm{~kg} b a g$ & Cement & $\$ 4.20$ \\
\hline$c^{3}$ & Sand & $\$ 11.80$ & $\mathrm{~m}^{2}$ & $\begin{array}{c}\text { Crushed } \\
\text { Concrete Debris }\end{array}$ & $\$ 2.25$ \\
\hline Total Price & & $\$ 4.40 / \mathrm{mm}^{+}$ & Tata Price & & $\$ 3.85 / \mathrm{m}^{2}$ \\
\hline
\end{tabular}

\section{Conclusions}

The proportion of the crushed concrete debris affects cement and water in a manner that it absorbs most of the water in the mixture. The concrete debris obtained a high slump and low compressive strength as its seventh day of curing. The amount of water in the mixture affects the consistency of the mortar mixture. The concrete debris mix, with $1: 3$ ratio of cement to crushed concrete debris with considerable slump and penetration, has an acceptable mobility as the standard mortar mix of the same cement to sand ratio.

The concrete debris having $1: 2^{3 / 4}$ cement to crushed concrete debris ratio of 2 in cubes is as compact as the standard mortar mix of the same cement to sand ratio. Mainly in mix proportion affects the consistency of workability of a mortar mix having $1: 2^{3 / 4}$ cement to crushed concrete debris ratio.

The advantages of using crushed concrete debris mix compared to the conventional mortar mix are: (1) it help in saving the environment from wastes disposal of to landfill, and (2) the need for virg in materials maybe reduced. The design mixtures of crushed concrete debris as alternative fine aggregate for arch itectural finishing mortar are: (1) a mixtu re of $1: 2 \frac{1}{2}$ ratio of cement to concrete debris, and (2) addition of water to obtain good flow.

\section{ACKNOWLEDGEMENTS}

The writer wish to express his sincere gratitude and deep appreciation to his former colleagues in FEATI University and Auckland University of Technology for their untiring guidance, inspiring encouragement and sincere concern for the completion of the research and Prof. Lucina Galera for her intellectual comments and suggestions towards the improvement of the manuscript.

\section{REFERENCES}

[1] S. Somayaji, Civil Engineering Materials, New York: Pearson Education, pp. 321-323, 2001

[2] Handoo and Mahajan, Civil Engineering Materials, $1^{\text {st }}$ ed. Quezon City: R.M. Garcia Publishing House, pp.156-165, 1992. 
[3] ASTM C-129, Standard Specifications for Non-Load bearing Concrete Masonry Units, ASTM, 2011.

[4] J. Remigio, "Coal Bottom Ash as Partial Replacement of Fine Aggregates in Hollow Load-Bearing Concrete Masonry Units," Undergraduate thesis, College of Engineering, Dela Salle University, Manila, 2003.

[5] J. Garcia, "Used of Glass as a Partial Replacement in on Site Concrete," Undergraduate thesis, College of Engineering, Dela Salle University, Manila, 2006.

[6] ASTM C-140, Standard Specifications for Fly Ash for Use as a Mineral Admixture in Portland cement, ASTM, 2011.

[7] ASTM C 136 - 95a, Standard Test Method for Sieve Analy sis of Fine and Coarse Aggregates, Annual Book of ASTM. 2011

[8] ASTM C 360 - 92, Standard Test Method for Ball Penetration in Freshly Mixed Hydraulic Cement Concrete, ASTM , 2011.

[9] ASTM C 87, Standard Test Method for Effect of Organic Impurities in Fine Aggregate on Strength of Mortar, Annual Book of ASTM , 2011,

[10] M. Handoo, Civil Engineering Materials. CRE Press, 1992

[11] J. Allen, Fundamentals of Building Construction: Materials and Methods, Wiley, 2008

[12] NSCP Section 703, Mortar and Grout, National Structural Code of the Philippines, Volume 2, 2010. 